\author{
글리세롤로부터 수증기 개질에 의한 수소 생산공정의 모델링, \\ 시뮬레이션 및 최적화 \\ 박정필* · 조성현* · 이승환** · 문동주*** · 김태옥* · 신동일*,† \\ *명지대학교 화학공학과 \\ 449-728 경기 용인시 처인구 명지로 116 \\ **JNK Heaters \\ 153-803 서울 금천구 가산디지털1로 168 \\ ***한국과학기술연구원 \\ 136-791 서울 성북구 화랑로 14 길 5 \\ (2014년 4월 1일 접수, 2014년 6월 13일 수정본 접수, 2014년 6월 19일 채택)
}

\title{
Modeling, Simulation and Optimization of Hydrogen Production Process from Glycerol using Steam Reforming
}

\author{
Jeongpil Park*, Sunghyun Cho*, Seunghwan Lee**, Dong Ju Moon***, Tae-Ok Kim* and Dongil Shin*, \\ *Department of Chemical Engineering, Myongji University, 116 Myongji-ro, Cheoin-gu, Yongin, Gyeonggi 449-728, Korea \\ **JNK Heaters, 168 Gasan digital 1-ro, Geumcheon-gu, Seoul 153-803, Korea \\ ***Korea Institute of Science and Technology, 5 Hwarang-ro 14-gil, Seongbuk-gu, Seoul 136-791, Korea \\ (Received 1 April 2014; Received in revised form 13 June 2014; accepted 19 June 2014)
}

\section{요 약}

본 연구에서는 바이오디젤 생산의 부산물인 글리세롤로부터 수증기 개질(Steam Reforming, SR) 반응을 통해 수소를 생산하는 공정의 모델링과 모사 및 최적화를 수행했다. 글리세롤을 이용한 수소 생산 방법은 기존의 수소 생산방법인 메탄의 수증기 개질법(Steam Methane Reforming, SMR)을 대체할 수 있는 새로운 방법으로 세계 여러 곳에서 연구가 진행 중이다. 글리세롤과 수증기의 기체 혼합물을 고온의 반응기 내에서 개질시켜 합성가스 $\left(\mathrm{CO}, \mathrm{H}_{2}\right)$ 를 생산하고, 합 성가스에 포함된 일산화탄소를 수성 가스 전화 반응(Water-Gas Shift, WGS)을 통해 수증기와 반응시켜 수소를 생성하 고, 최종적으로 Pressure Swing Adsorption (PSA) 공정을 통하여 이산화탄소와 수소를 분리하여 정제된 수소를 얻는다. 공정시뮬레이션 프로그램인 UniSim을 이용하여 시뮬레이션을 진행하였으며, 열효율 개선을 실시하여 운전 비용을 절 감하고자 하였다. 기존 연구인 미국 DOE와 독일 Linde의 글리세롤 이용 수소 생산공정과 수율 비교를 진행하였고, 수 소 에너지 인프라 구축에 기여하기 위한 최적의 생산방법을 제안하였다.

\begin{abstract}
For improved sustainability of the biorefinery industry, biorefinery-byproduct glycerol is being investigated as an alternate source for hydrogen production. This research designs and optimizes a hydrogen-production process for small hydrogen stations using steam reforming of purified glycerol as the main reaction, replacing existing processes relying on steam methane reforming. Modeling, simulation and optimization using a commercial process simulator are performed for the proposed hydrogen production process from glycerol. The mixture of glycerol and steam are used for making syngas in the reforming process. Then hydrogen are produced from carbon monoxide and steam through the water-gas shift reaction. Finally, hydrogen is separated from carbon dioxide using PSA. This study shows higher yield than former U.S. DOE and Linde studies. Economic evaluations are performed for optimal planning of constructing domestic hydrogen energy infrastructure based on the proposed glycerol-based hydrogen station.
\end{abstract}

Key words: Glycerol, Modeling, Simulation, Optimization, Economic Analysis, Steam Reforming

\footnotetext{
${ }^{\dagger}$ To whom correspondence should be addressed.

E-mail: dongil@mju.ac.kr

†이 논문은 서울대학교 윤인섭 교수님의 정년을 기념하여 투고되었습니다.

This is an Open-Access article distributed under the terms of the Creative Commons Attribution Non-Commercial License (http://creativecommons.org/licenses/by$\mathrm{nc} / 3.0$ ) which permits unrestricted non-commercial use, distribution, and reproduction in any medium, provided the original work is properly cited.
} 


\section{1. 서 론}

산업혁명 이후부터 이어진 화석연료 사용으로 인하여 환경오염 문 제가 크게 이슈화 되고 있으며 화석연료가 점차 고갈되어 감에 따라 이를 대체할 수 있는 청정에너지에 대한 연구가 전 세계적으로 활발 하게 진행되고 있다. 그로 인해 청정에너지 중 경제성과 친환경성을 갖춘 수소에너지에 대한 관심이 급증하고 있으며, 이를 이용한 연료 전지, 수소자동차, $\mathrm{HCNG}$ 등의 개발도 실생활에 적용할 수 있을 정 도의 발전이 진행되고 있다. 그러나 수소 에너지에 대한 연구 진척 에 비해 수소를 안정적으로 생산·공급할 수 있는 인프라는 턱없이 부 족한 현실이다. 미국, 유럽, 일본 등의 주요 선진국들이 수소 인프라 구축에 많은 신경을 쓰고 있는 만큼 국내에서도 국내 실정에 적합한 수소 인프라 구축 방법을 모색할 필요가 있다.

수소 생산의 대부분은 화석연료의 가공을 통해 이루어지고 있고, 이중에서 천연가스의 개질 반응을 통한 수소 생산이 가장 큰 비중을 차지한다. 최근 미국에서 시작된 셰일가스 여파로 인하여 천연가스 가격이 많이 하락하긴 했으나 국내의 경우에는 천연가스를 수입하여 사용하고 있기 때문에 경제성이 떨어진다. 이 밖에는 태양광, 풍력 등 대체 전원인 신재생 에너지를 이용한 물의 전기분해 방식이 있으 나, 우리나라의 경우 2012년 기준으로 신재생 에너지의 사용 비율이 전체 에너지 사용의 $0.3 \%$ 에 불과한데다가[1] 여름, 겨울철에는 전력 소비 증가로 인한 전력 부족 현상이 매년 발생하고 있기 때문에 물 의 전기분해 방식은 다소 비효율적이다. 화석연료를 대체하기 위한 또 다른 방법은 친환경 연료를 사용하는 것으로, 대표적인 친환경 연 료에는 곡물 및 바이오매스의 발표를 통해 얻는 바이오 에탄올과 유 지의 에스테르화 반응을 통해 생산하는 바이오디젤이 있는데, 국내 에서는 바이오에탄올은 사용하지 않고, 현재 일반 디젤에 바이오디 젤을 혼합하여 사용하고 있다. Table 1은 우리나라에서 사용하는 바 이오연료인 바이오디젤의 연간 생산량을 나타낸 것이다[1]. 바이오 디젤은 화석연료를 이용하여 생산하는 것이 아니라서 국제적으로 탄 소 중립 연료로 인정받은 친환경 연료이며, 장기적으로 국가정책을 통해 일반 디젤과의 혼합 비율을 높여 갈 예정이다. 바이오디젤은 여 러 종류의 지질로부터 생산할 수 있는데, 그 지질의 원료는 먹을 수 있는 식물인 1세대부터 해조류인 3세대까지 종류가 다양하다[2]. 바 이오디젤을 생산하는 과정에서 부산물로 글리세롤이 생산되는데, 이는 생산되는 바이오디젤의 $10 \mathrm{wt} \%$ 에 해당하는 양으로, 주로 화장품, 제 약 등 일부 사용량을 제외하고는 대부분의 양이 폐기되고 있는 실정 이다.

현재 미국 및 독일 등 선진국에서는 글리세롤을 이용한 수소 생산에 대하여 연구가 진행되고 있지만 국내에서는 연구가 아직 진행된 바 가 없으며, 추후 국가 에너지 정책에서 바이오디젤과 일반 디젤의 혼 합 비율이 높아질 경우 바이오디젤 생산량 증가와 더불어 글리세롤 생산량도 함께 늘어나게 되므로 이에 대한 대비책을 미리 세워둘 필 요가 있다. 본 연구에서는 바이오디젤 생산과정에서 생성되는 글리 세롤을 이용하여 개질반응, 수성가스 전화반응과 정제과정을 거쳐 수소를 생산하는 $30 \mathrm{Nm}^{3} / \mathrm{h}$ 규모의 수소 생산공정의 기본개념 설계를 공정설계 시뮬레이션 프로그램인 UniSim R410을 이용하여 진행하
였으며, 최적화 및 경제성 검토를 통하여 국내 실정에 맞는 수소 스 테이션용 수소 생산공정을 제안하였다.

\section{2. 글리세롤의 활용 및 연구 동향}

\section{2-1. 글리세롤 활용}

글리세롤은 여러 전환공정을 통하여 다양한 화학물질로 전환된다. 글리세롤을 열분해하여 합성가스를 생성할 수 있으며, 이를 이용하 여 메탄올, 에탄올, 알켄, 이소부탄 등을 합성할 수 있다. 특히, 합성 가스에 존재하는 일산화탄소는 WGS 반응을 통하여 물과 반응시켜 더 많은 수소를 생산 할 수 있다. 합성가스로 생산한 메탄올과 수소는 또 다른 공정을 통하여 다양한 화학제품을 생산할 수 있고, 요소와 반응시키면 글리세롤카보네이트를 생산할 수도 있다. 이는 낮은 독 성, 생분해성, 높은 끓는점을 가지고 있으며, 기체 분리막의 새로운 성분물질, 폴리우레탄 폼, 계면활성제 성분, 비휘발성 활성용매, 코 팅제, 페인트, 합성 세제 등에 사용된다. 저가의 글리세롤카보네이트는 폴리카보네이트와 폴리우레탄 생산의 새로운 중합 원료로도 사용될 수 있을 뿐만 아니라 고가의 글리시돌(glycidol)과 같은 분자물질의 출발물질로도 사용할 수 있다[3]. 이 외에도 여러 가지 반응을 통하여 수많은 유용한 물질들을 만들 수 있는데 Fig. 1은 글리세롤을 기반 으로 다양한 화학적 처리 및 반응을 통하여 생산할 수 있는 공정들을 간단하게 표시한 것이다. 산업적으로 글리세롤을 가장 많이 사용하는 곳은 제약분야로, 약 $18 \%$ 의 글리세롤을 사용하고 있으며, 그 다음으 로 생활용품 분야에 약 $16 \%$ 가 사용된다. 폴리에테르를 제조하는데 약 $14 \%$ 가 사용되며, 그 외에도 식품, 알키드 수지, 트리아세틴, 담배, 세제, 셀로판, 폭발물 등에 사용된다[2].

\section{2-2. 메탄을 이용한 수소 생산}

대부분이 메탄으로 구성되어 있는 천연가스를 개질시켜 수소를 생 산하는 방법이 가장 보편적이다. 수소 스테이션 내에서 자체적으로 수소를 생산해서 공급하는 경우에는 대부분 메탄으로부터 수소를 제 조하는데, 그 전체 반응식은 아래와 같다.

$$
\mathrm{CH}_{4}+2 \mathrm{H}_{2} \mathrm{O} \rightleftarrows \mathrm{CO}_{2}+4 \mathrm{H}_{2} \quad \Delta \mathrm{H}=165 \mathrm{~kJ} / \mathrm{mol}
$$

메탄을 이용하여 수소를 생산하는 공정은 글리세롤을 이용한 방 법과 거의 유사하다. 즉, 수증기를 이용한 개질 반응기를 거쳐 수소, 일산화탄소를 생산하고, WGS 반응을 통하여 일산화탄소를 수소로 전환하는 과정을 거친 후 PSA를 이용하여 수소를 분리 및 정제하는 과정으로 이루어진다[4].

\section{2-3. 글리세롤을 이용한 수소 생산}

2-3-1. Linde

독일의 가스회사인 Linde사에서는 독일 Leuna 지역에 $50 \mathrm{Nm}^{3} / \mathrm{h}$ 규모의 글리세롤을 이용한 수소 생산 pilot 플랜트를 건설하여 2011 년에 첫 운전에 돌입한 바 있다. Fig. 2는 Linde사에서 설계한 글리 세롤을 이용한 수소 생산 공정의 기본 개념도이다. 이 플랜트에서는 바이오디젤의 부산물로 생산되는 Crude글리세롤을 정제 과정을 거쳐

Table 1. Changes of bio-fuel production in Korea[1]

\begin{tabular}{ccccccccc}
\hline \hline $10^{3}$ TOE & 2007 & 2008 & 2009 & 2010 & 2011 & 2012 & compare with 2012 & Compared with World Production in 2012 \\
\hline Korea & 74 & 141 & 343 & 491 & 211 & 211 & $-0.3 \%$ & $0.4 \%$ \\
\hline
\end{tabular}




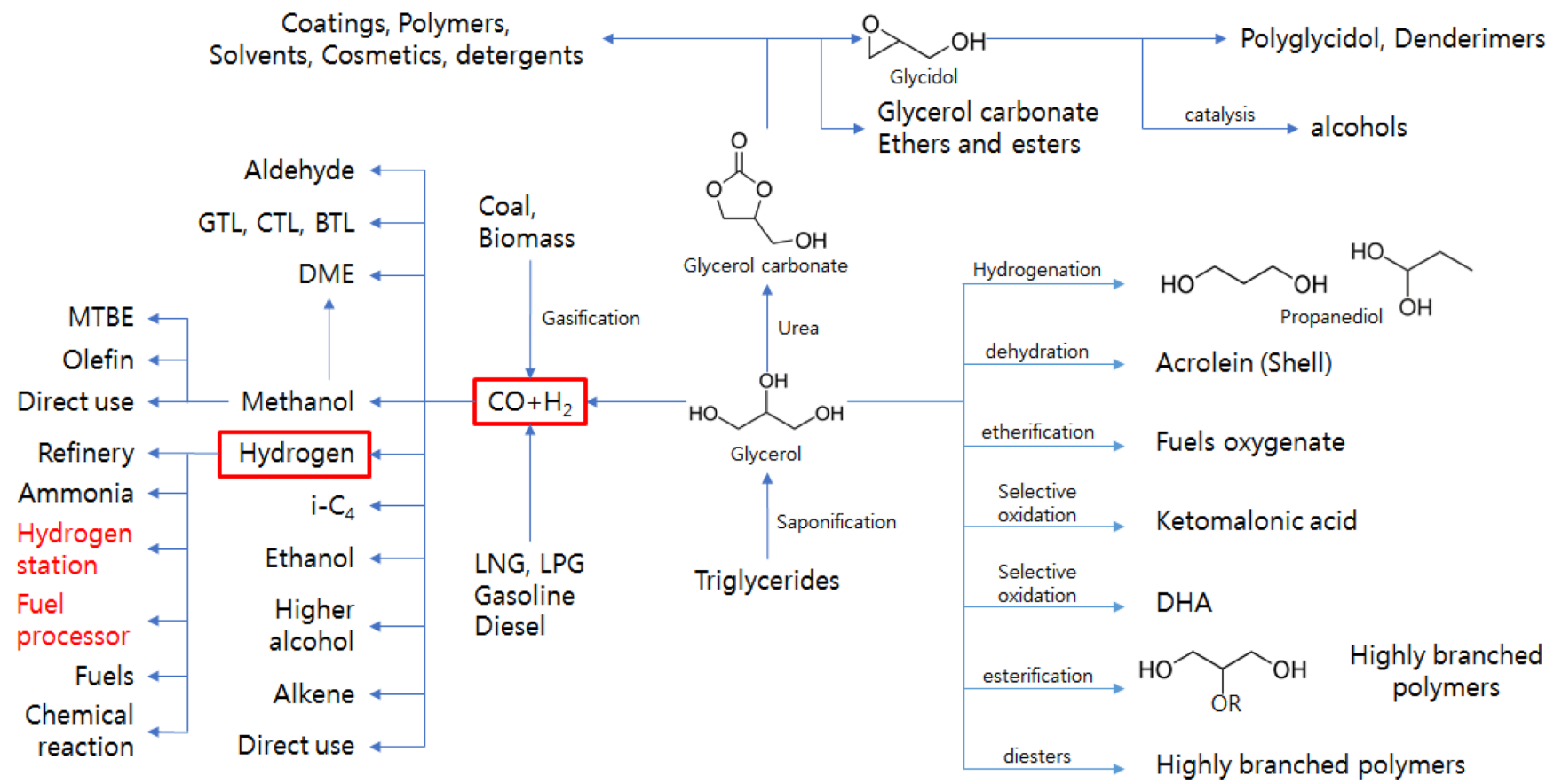

Fig. 1. Conversion process of glycerol.

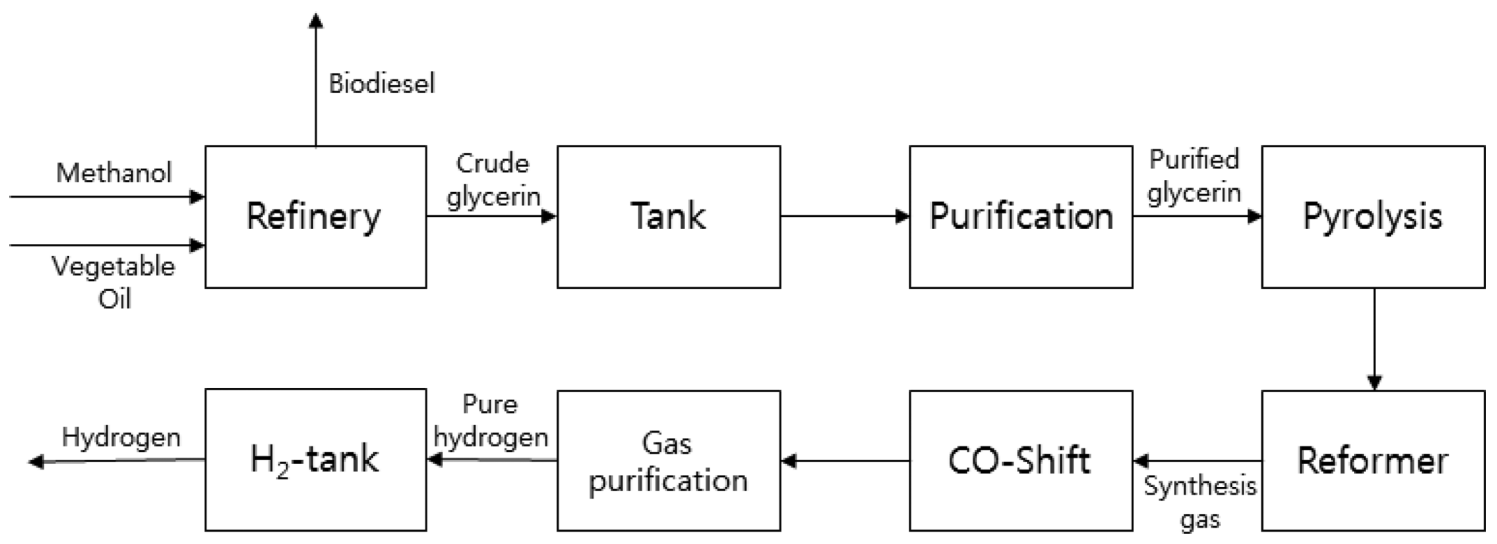

Fig. 2. Hydrogen production process from glycerol by Linde [5].

염 성분을 제거하여 순도를 높이고, $30 \mathrm{bar}$ 의 압력으로 $650-800{ }^{\circ} \mathrm{C}$ 에서 열분해과정, $750-900{ }^{\circ} \mathrm{C}$ 에서 개질 과정을 거쳐 합성가스를 생 성한다. 생성된 합성가스는 $320{ }^{\circ} \mathrm{C}$ 에서 일산화탄소 전환과정 $(\mathrm{CO}-$ shift)을 통하여 추가적으로 수소를 생산한다. 이 과정에서 수소 수율 이 증가하며, 마지막으로 $86 \%$ 효율의 PSA 과정을 통하여 수소와 함 께 생성된 이산화탄소를 분리하여 고순도의 수소를 생산한다. 생산 량은 $4.7 \mathrm{~kg} / \mathrm{h}$ 이며, 수소의 수율은 약 $77.5 \%$ 이다[5].

\section{2-3-2. 미국 Department of Energy (DOE)}

미국 DOE에서는 Argonne National Laboratory와 함께 2009년에 글리세롤을 이용한 수소 생산공정에 대하여 타당성 조사를 실시했다. Fig. 3은 DOE에서 설계한 글리세롤 이용한 수소 생산공정의 개념도를 나타낸 것이다. 경제성 평가결과 글리세롤 가격이 $1.07 \mathrm{USD} / \mathrm{gal}(10$ cent/lb)일 경우에 $4.86 \mathrm{USD} / \mathrm{kg} \mathrm{H}_{2}$ 으로 계산되었으며, 원료인 crude 글리세롤의 경우 수소 판매 가격의 $44 \%$ 를 차지하는 것으로 조사되 었다. 다만, 글리세롤을 이용한 수소 생산방법의 경우 현재 수소 생
산방법에 비해 원료의 가격, 공정의 효율 등의 문제로 인하여 수소 생산 가격이 다소 높다. 수소 생산 단가를 유지하기 위하여 $\mathrm{DOE}$ 에 서는 원료인 글리세롤의 가격이 $0.74 \mathrm{USD} / \mathrm{gal}$ (7 cent/lb)까지 하락 해야 하며, 공정효율의 개선, 초기 투자비의 절감 등을 달성해야 한 다고 제시하고 있다. $\mathrm{DOE}$ 에서 설계한 공정의 경우에는 수소 수율이 약 $69 \%$ 이었다[6].

\section{2-3-3. 기타 연구}

기타 미국 대학에서도 글리세롤을 이용한 수소 생산공정에 대한 연구를 지속적으로 진행해왔다. 그 중 대표적인 경우가 Sushil Adhikari 등의 연구이다. 이 저자는 수증기 개질방법을 이용하여 글리세롤로 부터 수소를 생산할 경우의 반응 조건에 대하여 1 기압 $960 \mathrm{~K}$ 조건에서 물과 글리세롤의 비가 9:1일 경우에 1몰의 글리세롤에서 6 몰의 수소를 생산할 수 있다고 하였다[7]. 이는 약 $85.7 \%$ 에 해당하는 수소 수율 이며, 탄소 생성 반응이 가장 적게 일어나기 때문에 촉매 표면에 탄 소 침적으로 인한 촉매의 비활성화로 인한 손해를 최소화 할 수 있 


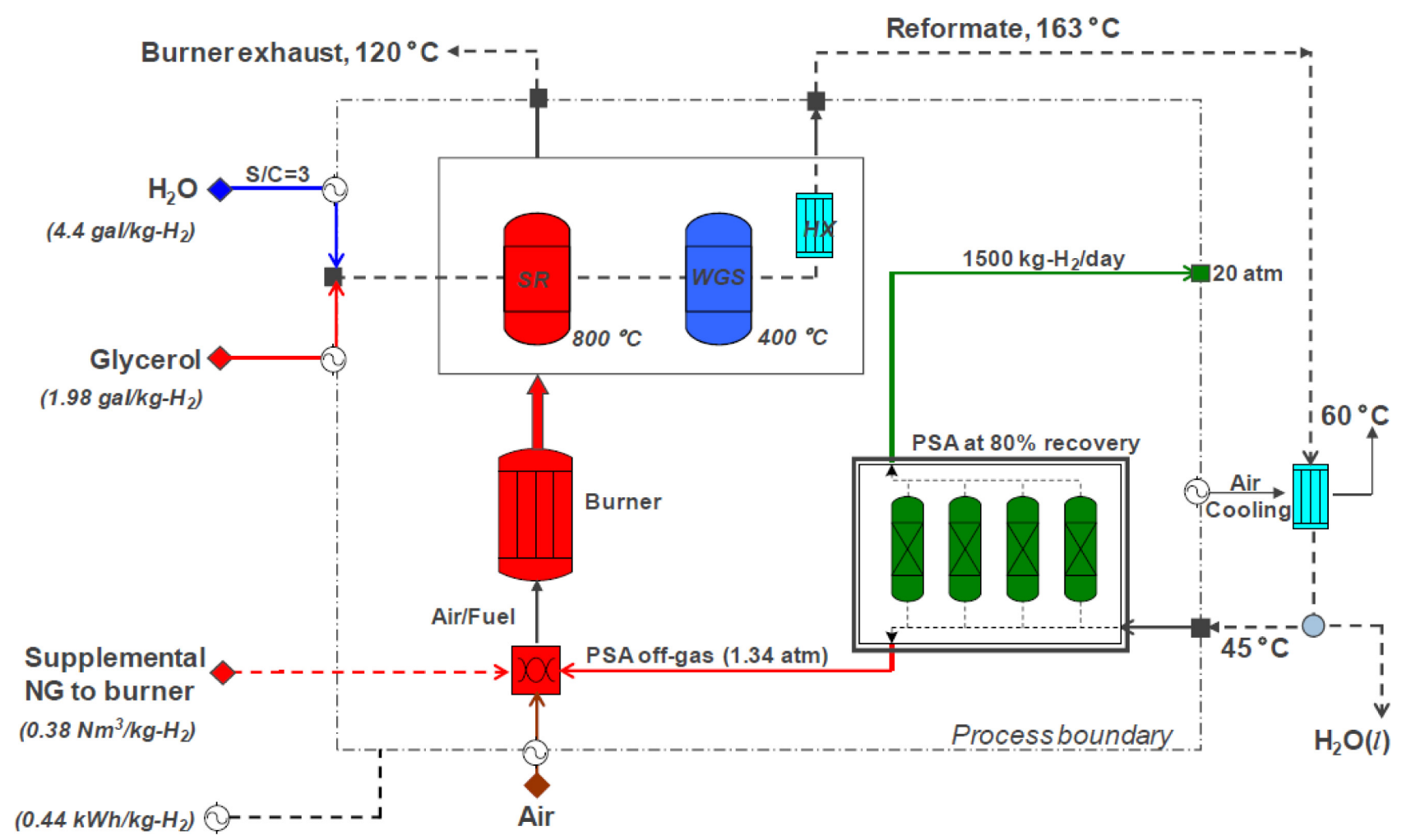

Fig. 3. Hydrogen production process from glycerol by DOE [6].

다고 설명한다. 이 외에도 다양한 논문에서 속도론 및 촉매에 대한 연구가 다양하게 진행되었으며 [8-10], 수증기 개질방법이 아닌 다른 개질방법인 자열 개질반응(Autothermal Reforming, ATR), 수상 개 질반응(Aqueous-Phase Reforming, APR)에 대하여도 다양한 연구가 진행되었다[11].

\section{3. 설계 공정의 개요 및 모델링}

\section{3-1. 공정 개요}

바이오디젤 생산 공정에서 부산물로 생성되는 글리세롤은 주산물 인 바이오디젤의 $10 \mathrm{wt} \%$ 만큼 생산되고, 이를 이용하여 수소를 생산 하는데, 그 과정에서 첨가된 여러 화학 약품 때문에 글리세롤 내부
에는 다수의 염이 포함되어 있다. 이 crude글리세롤을 이용하여 수 소를 생산하기 위해서는 물을 이용하여 염을 씻어내는 방법 또는 증 류를 이용한 정제 등 다양한 방법을 이용하여 글리세롤의 순도를 높 여야 한다. 그러나 본 논문에서는 글리세롤 정제과정에 대해서는 시 뮬레이션 하지 않고, 원료를 순수 글리세롤로 사용했다고 가정하였다.

전체적인 공정의 개념도는 Fig. 4에서 나타낸 바와 같다. 글리세롤은 9배에 해당하는 물과 혼합된 후 히터를 거치면서 개질 반응에 적합 한 온도인 약 $800{ }^{\circ} \mathrm{C}$ 까지 가열된다. 이렇게 가열된 혼합원료는 개질 기로 도입되어 열분해 과정을 거치게 되는데, 이 과정에서 글리세롤은 일산화탄소와 수소로 이루어진 합성가스를 생성하게 된다.

개질기에서 생성된 일산화탄소와 수소 및 수증기는 냉각기를 거쳐 WGS 반응기로 도입된다. 이 반응기에서는 일산화탄소와 물이 반응
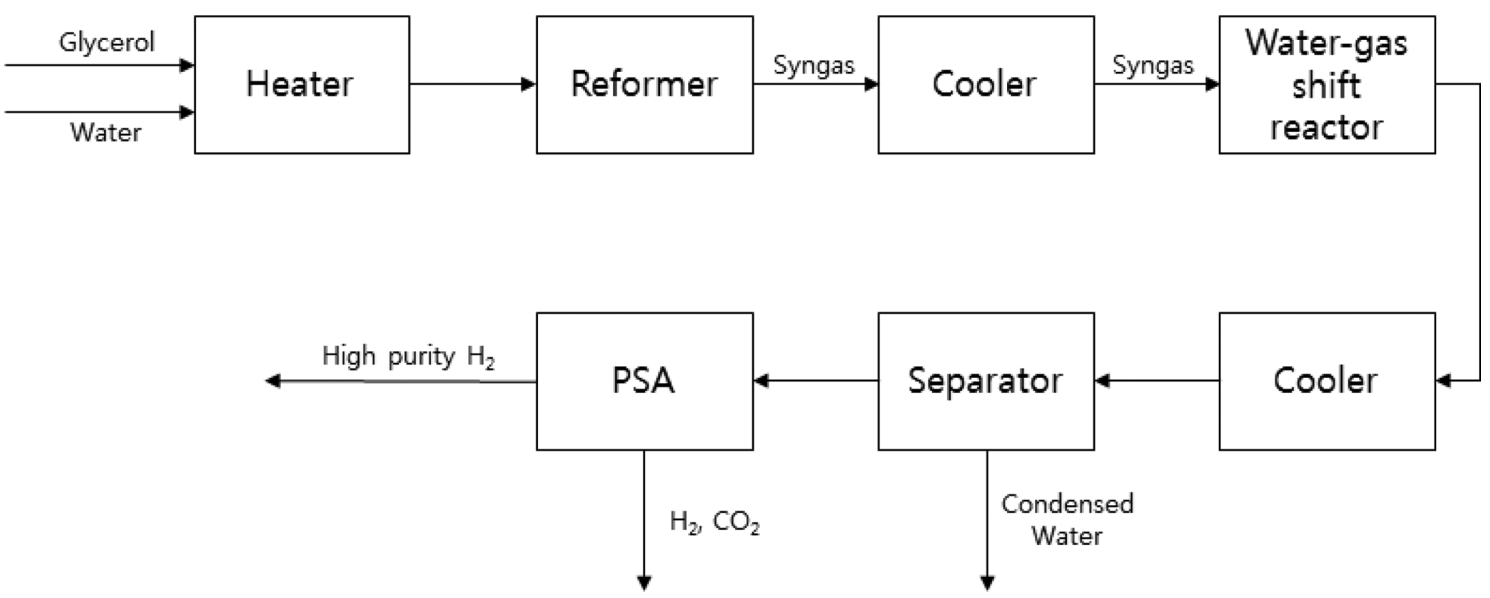

Fig. 4. Block flow diagram of the proposed hydrogen production process from glycerol. 
을 하면서 이산화탄소와 수소가 생성되기 때문에 개질기에서 넘어온 일산화탄소와 수증기를 이용하여 수소의 생산량을 최대화할 수 있다. 글리세롤을 이용한 수소 생산 공정의 전체 반응식은 식 (2)와 같으 며 이론적으로는 글리세롤 1몰당 수소 7몰을 생산할 수 있다.

$$
\mathrm{C}_{3} \mathrm{H}_{8} \mathrm{O}_{3}+3 \mathrm{H}_{2} \mathrm{O} \rightleftarrows 3 \mathrm{CO}_{2}+7 \mathrm{H}_{2} \quad \Delta \mathrm{H}=128 \mathrm{~kJ} / \mathrm{mol}
$$

생산된 이산화탄소와 수소 및 미반응 수증기는 다시 한 번 냉각기를 거치게 된다. 이 과정에서 미반응 수증기는 응축되어 분리기를 통해 분리하고, 남은 이산화탄소와 수소는 분리 공정을 통해 분리하여 고 순도의 수소를 생산하게 된다.

\section{3-2. 개질기의 선정}

\section{3-2-1. 수증기 개질반응}

수증기 개질반응은 원료를 고온의 수증기를 이용하여 개질시키는 방법으로, 현재 천연가스를 이용하여 수소를 만드는 공정에서 가장 많이 사용하는 방법이다. 개질기 내부에서는 여러 가지 반응이 일어 나는데 식 (3)-(5)에 해당하는 반응이 이에 해당한다. 반응기 내에서 일어나는 글리세롤 분해반응은 강력한 흡열반응이기 때문에 반응이 진행될수록 반응기 내부 온도가 감소하게 된다. 이것은 글리세롤의 분해 반응 속도를 감소시키기 때문에 외부에서 지속적으로 에너지를 공급해야 한다. 수증기 개질기 내에서 발생하는 부반응을 통해 생성 된 일산화탄소와 수소는 서로 반응을 일으키면서 메탄을 생성하게 되는데, 이는 메탄의 분해 반응으로 이어져 탄소를 생성하여 촉매의 비활성화를 일으키기도 하고, 수소와 일산화탄소가 함께 반응한다는 점에서 전체적인 수소 수율을 떨어뜨린다는 단점이 있기 때문에 최 대한 억제하는 방향으로 진행해야 한다. 이를 위해서는 반응기에 투 입되는 수증기의 양이 많을수록 좋은데, S. Adhikari 등[7]에 의하면 물 : 글리세롤의 비가 9:1일 경우에 메탄 생성을 최소화 할 수 있다 고 하였다.

$$
\begin{aligned}
& \mathrm{C}_{3} \mathrm{H}_{8} \mathrm{O}_{3} \rightleftarrows 3 \mathrm{CO}+4 \mathrm{H}_{2} \quad \Delta \mathrm{H}=251 \mathrm{~kJ} / \mathrm{mol} \\
& \mathrm{CO}+3 \mathrm{H}_{2} \rightleftarrows \mathrm{CH}_{4}+\mathrm{H}_{2} \mathrm{O} \quad \Delta \mathrm{H}=-206 \mathrm{~kJ} / \mathrm{mol} \\
& \mathrm{CH}_{4} \rightleftarrows \mathrm{C}+2 \mathrm{H}_{2} \quad \Delta \mathrm{H}=-75 \mathrm{~kJ} / \mathrm{mol}
\end{aligned}
$$

\section{3-2-2. 자열 개질반응}

자열 개질반응의 경우에는 수증기 개질반응에서 이루어지는 식 (3)-(5)반응이 동일하게 이루어진다. 그러나 수증기 개질반응과는 다 르게 글리세롤과 수증기 이외에도 산소가 따로 반응물질로 투입된다. 투입된 산소는 글리세롤과 반응을 일으켜 부분 산화반응(Partial Oxidation, PO)을 일으키게 되는데, 이는 강력한 발열반응이라서 반 응이 진행되는 과정에서 상당한 열을 방출하게 된다. 부분 산화반응 은 수증기 개질 반응에서 발생하는 글리세롤 분해반응인 식 (3)이 강 력한 흡열반응인 것과 대조적인데, 이 두 가지 반응이 동시에 한 개 질기 내에서 일어나게 되면 글리세롤 분해 반응에서 필요로 하는 열 을 부분 산화반응에서 공급하기 때문에 수증기 개질반응에 비해 개 질기 내부온도 유지에 드는 에너지 비용이 감소하게 된다는 점이 장 점이라고 할 수 있다. 그러나 수증기 개질반응에 비해 최종적으로 생 성되는 수소의 양이 상대적으로 적고, 반응에 필요한 산소를 공급하 기 위해서 공기 중에서 산소를 분리하여 공급하는 장치도 추가해야 한다는 단점이 있다.

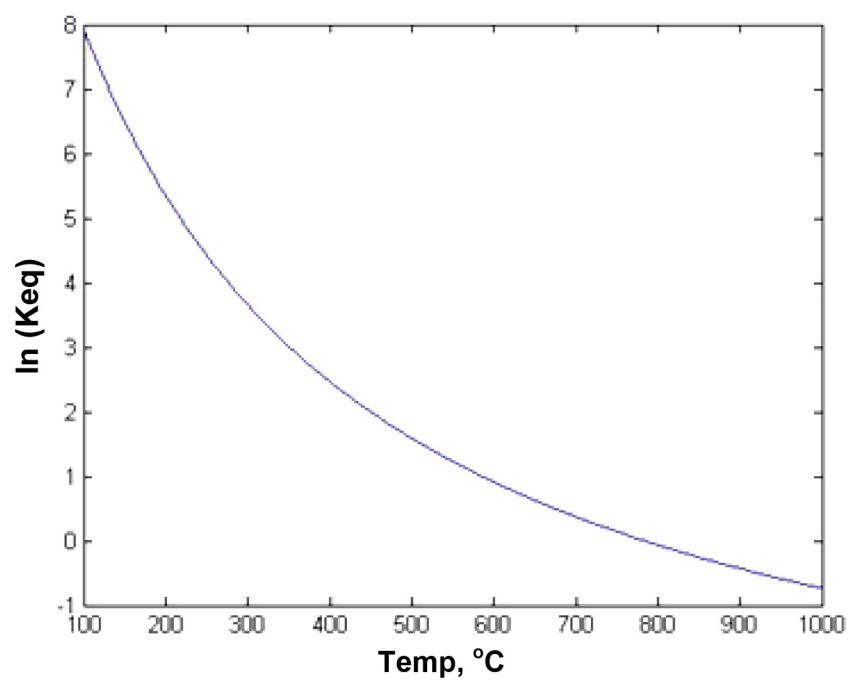

Fig. 5. Changing of equilibrium constant.

$$
\mathrm{C}_{3} \mathrm{H}_{8} \mathrm{O}_{3}+\frac{3}{2} \mathrm{O}_{2} \rightleftarrows 3 \mathrm{CO}+4 \mathrm{H}_{2} \quad \Delta \mathrm{H}=-598 \mathrm{~kJ} / \mathrm{mol}
$$

본 연구에서는 글리세롤을 이용한 수소 생산수율을 높이기 위하여 생산량이 적은 자열 개질방법 보다는 수증기를 이용한 개질방법을 이용하여 설계를 진행하였다. 또한 수증기 개질 반응기의 경우 기존 수소 생산방법인 천연가스를 이용한 메탄 수증기 개질반응에서도 사 용하는 가장 보편적인 개질기이기 때문에 메탄 대신 글리세롤을 수 증기 개질 하더라도 반응기 구조 측면에서는 큰 변화 없이도 사용할 수 있을 것이라는 가정 하에 선택하였다.

\section{3-3. 수성가스 전화반응}

개질기를 거쳐 생성된 합성가스는 WGS 반응기로 투입되고, 반응기 내에서는 식 (7)번과 같은 반응이 진행된다. WGS 반응은 발열반응 으로, 반응이 진행되기 위해서는 반응 온도가 낮을수록 좋다. 식 (8)은 WGS 반응의 평형상수를 나타낸 식이며, Fig. 5는 온도 변화에 따른 평형상수의 변화 그래프를 나타낸 것이다[12].

$$
\begin{aligned}
& \mathrm{CO}+\mathrm{H}_{2} \mathrm{O} \rightleftarrows \mathrm{CO}_{2}+\mathrm{H}_{2} \quad \Delta \mathrm{H}=-41 \mathrm{~kJ} / \mathrm{mol} \\
& \ln \left(K_{e q}\right)= \frac{5693.5}{\mathrm{~T}}+1.077 \ln \mathrm{T}+5.44 \times 10^{-4} \mathrm{~T}-1.125 \times 10^{-7} \mathrm{~T}^{2} \\
& \quad-\frac{49170}{\mathrm{~T}^{2}}-13.148
\end{aligned}
$$

WGS 반응에서는 반응에 따라 반응기의 온도가 상승하는데, WGS 반응의 평형상수는 온도가 낮을수록 높기 때문에 온도가 낮아야지만 정반응이 잘 일어난다. 즉, 반응과정에서 발생되는 에너지를 제거하는 것이 매우 중요하다. 일반적으로 WGS 반응은 High Temperature Shift (HTS) 및 Low Temperature Shift (LTS)로 구분된다. HTS의 경우는 $310-450{ }^{\circ} \mathrm{C}$, LTS의 경우는 $200-250{ }^{\circ} \mathrm{C}$ 에서 반응이 진행되는데[13], 둘 다 사용하는 경우에는 수율이 조금 더 올라간다는 장점이 있지만 반응기의 추가로 인한 설비비용 및 유지비용의 증가라는 단점이 있 다. LTS에서는 주로 구리계 촉매를 사용하는데, 석탄이나 탄화수소 에 많이 포함되어 있는 황 성분에 의해 피독되는 단점이 있지만, 바 이오디젤 생산과정에서 부산물로 생성된 글리세롤의 경우 황을 포함 
하고 있지 않기 때문에 LTS 반응만으로도 충분한 수소 수율을 얻을 수 있다. 특히, $200{ }^{\circ} \mathrm{C}$ 에서는 반응기 출구의 일산화탄소 농도가 $0.1-0.3 \%$ 밖 에 남지 않을 정도로 효율이 좋다. 이러한 이유로 본 연구에서는 HTS 는 사용하지 않고, LTS만을 사용하였으며, LTS 반응기 반응 범위 중 에서 가장 낮은 온도인 $200{ }^{\circ} \mathrm{C}$ 에서 $\mathrm{WGS}$ 반응을 시뮬레이션 하였다.

\section{3-4. Pressure swing adsorption (PSA)}

PSA 방법은 고압의 흡착단계와 저압의 탈착단계를 거치면서 흡착 제를 이용하여 기체를 분리하는 공정으로, 흡작제로는 제올라이트 및 활성탄이 주로 사용되고 있다. 제올라이트는 저압영역에서 높은 흡착량을 갖기 때문에 고순도 제품 생산에 사용되고, 활성탄은 제올 라이트에 비해 한계 흡착량이 높아서 널리 사용된다[14]. 이산화탄 소와 수소의 혼합가스는 PSA를 통해 분리하게 되는데, Cheng-tung Chou 등[15]에 따르면 상온의 조건에서 2-Stage, Dual-bed, 8-Step로
설계한 결과, $99.98 \%$ 의 순도를 가진 수소를 $78.55 \%$ 의 회수를 통하여 생산할 수 있다고 하였다.

본 논문에서는 PSA를 위하여 UniSim 설계 프로그램 내에서 제공 하는 Component Splitter를 이용하였으며, 수소의 회수율은 약 $80 \%$, 순도는 $100 \%$ 로 가정하고, 시뮬레이션을 진행하였다.

\section{3-5. 제안하는 공정의 block diagram}

Fig. 4에서 제시한 글리세롤을 이용한 수소 생산 공정의 개념도를 이용하여 열효율 및 최적화를 고려하여 개선된 개념도를 Fig. 6에 나 타내었다. 혼합된 원료들은 개질기로 들어가기 전에 가열하여 개질에 적합한 온도인 $800^{\circ} \mathrm{C}$ 로 가열하기 위해 히터를 사용하는데, 그 이전 에 개질기를 거쳐서 생산된 합성가스를 이용하여 열교환을 하면 히 터에서 소모될 에너지를 절약함과 동시에 WGS 반응기로 도입될 합 성가스의 온도를 미리 낮추어서 냉각기에서 소모될 에너지를 절약할

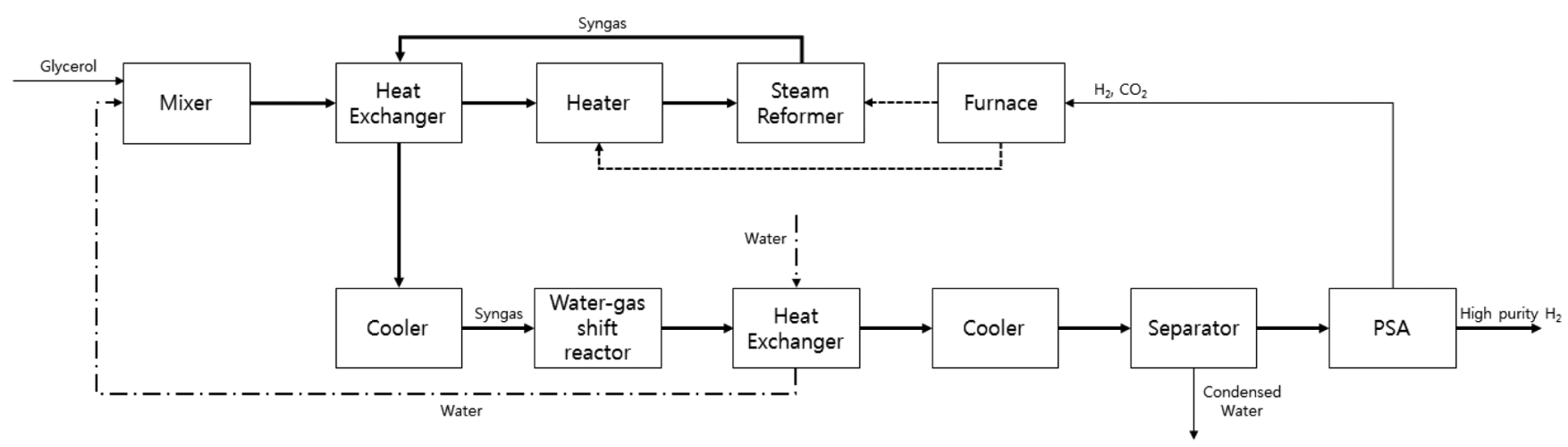

Fig. 6. Improved block flow diagram of the proposed hydrogen production process from glycerol.

Table 2. Flow sheet of basic process

\begin{tabular}{|c|c|c|c|c|c|}
\hline Name & Glycerol & Water & Feed & After SR & "Heated Feed \\
\hline Vapour Fraction & 0.0000 & 0.0000 & 0.0000 & 1.0000 & 1.0000 \\
\hline Temperature (C) & 25.00 & 25.00 & 23.54 & 800.0 & 800.0 \\
\hline Pressure $(\mathrm{kPa})$ & 506.6 & 506.6 & 506.6 & 304.0 & 506.6 \\
\hline Molar Flow (kgmole/h) & 0.2500 & 2.250 & 2.500 & 3.948 & 2.500 \\
\hline Mass Flow (kg/h) & 23.02 & 40.53 & 63.56 & 63.12 & 63.56 \\
\hline Std Gas Flow (STD_m³ $/ \mathrm{h})$ & 5.911 & 53.20 & 59.11 & 93.35 & 59.11 \\
\hline Name & After WGS Gas & After WGS Liq & Cooled Gas & Condensed Water & Sep Gas \\
\hline Vapour Fraction & 1.0000 & 0.0000 & 0.6001 & 0.0000 & 1.0000 \\
\hline Temperature (C) & 200.0 & 200.0 & 32.75 & 32.75 & 32.75 \\
\hline Pressure $(\mathrm{kPa})$ & 202.6 & 202.6 & 709.3 & 709.3 & 709.3 \\
\hline Molar Flow (kgmole/h) & 3.941 & 0.0000 & 3.941 & 1.576 & 2.365 \\
\hline Mass Flow (kg/h) & 63.00 & 0.0000 & 63.00 & 28.43 & 34.6 \\
\hline Std Gas Flow (STD_m³ $/ \mathrm{h}$ ) & 93.18 & 0.0000 & 93.18 & 37.26 & 55.91 \\
\hline Name & Hydrogen & off gas & WGS Inlet & Liq Out & Comp Gas \\
\hline Vapour Fraction & 1.0000 & 0.9890 & 1.0000 & 0.0000 & 1.0000 \\
\hline Temperature (C) & 26.40 & 26.40 & 200.0 & 800.0 & 324.3 \\
\hline Pressure $(\mathrm{kPa})$ & 709.3 & 709.3 & 304.0 & 304.0 & 709.3 \\
\hline Molar Flow (kgmole/h) & 1.315 & 1.049 & 3.941 & $4.427 \mathrm{e}-002$ & 3.941 \\
\hline Mass Flow (kg/h) & 2.651 & 31.91 & 63.00 & 0.5623 & 63.00 \\
\hline Std Gas Flow (STD_m³ $/ \mathrm{h})$ & 31.10 & 24.81 & 93.18 & 1.047 & 93.18 \\
\hline Name & Q1 & Q2 & Q3 & Q4 & Q5 \\
\hline Heat Flow $(\mathrm{kJ} / \mathrm{h})$ & $2.240 \mathrm{e}+005$ & $6.118 \mathrm{e}+004$ & $8.335 \mathrm{e}+004$ & $-2.885 e+004$ & $-1.685 \mathrm{e}+004$ \\
\hline Name & Q6 & Q7 & Q8 & & \\
\hline Heat Flow $(\mathrm{kJ} / \mathrm{h})$ & $1.074 \mathrm{e}+005$ & 0.0000 & -979.0 & & \\
\hline
\end{tabular}

Korean Chem. Eng. Res., Vol. 52, No. 6, December, 2014 
수 있다. WGS에서 생성된 수소와 이산화탄소는 초기에 원료로 도 입되는 물과의 열교환을 거치면서 일차적으로 냉각되고, PSA 단계 에 들어가기 전에 수분을 $0.7 \%$ 이하로 감소시켜야 하기 때문에 또 한 번의 냉각기를 거치며 이차적으로 냉각되며 분리기를 통하여 응 축된 물을 제거하게 된다. PSA에서 $80 \%$ 의 회수율로 $100 \%$ 의 순도를 가진 수소를 분리해 낸 후 남은 잔여 수소 및 이산화탄소는 연소를 통하여 개질기 및 히터의 에너지 공급원으로 사용한다.

\section{4. 결과 및 고찰}

\section{4-1. 공정 시뮬레이션을 통한 $30 \mathrm{Nm}^{3} / \mathrm{h}$ 규모 공정의 개념 설계}

해당 시뮬레이션은 공정 설계 시뮬레이션 프로그램인 UniSim R410 을 이용했다. 실제 실험 데이터를 이용하여 Conversion 반응기를 이 용하여 실제 전환율을 적용하여 시뮬레이션을 실시하였으며, 마찬가 지로 WGS 반응기의 경우에는 반응에 대한 평형상수를 반영하여 Equilibrium 반응기를 이용하여 시뮬레이션을 실시하였다[10]. 위에 서 기술했던 Sushil Adhikari 등의 열역학적 연구에서는 수증기 개질 반응은 공정의 압력이 상압에 이를 정도로 낮아야 효율이 좋다고 설 명하였으나[7], 생성된 수소 및 이산화탄소가 분리를 위하여 PSA 과정을 거칠 때는 압력이 높을수록 효율이 높고, 생성된 수소의 고 압 압축을 통한 보관을 위해서도 전체적인 반응의 압력이 높아야 하 기 때문에 원료의 투입 단계부터 $5 \mathrm{~atm}$ 의 압력으로 시뮬레이션을 실 시했다. 개질기의 운전 조건의 경우 기존 문헌의 열역학적 분석 결과[7] 를 토대로 실시한 실험 데이터들을 기반으로 결정하였으며, WGS는 기존에 알려진 반응 온도 범위 내에서 3.3절의 평형상수를 고려하였 을 때 가장 효율이 높은 온도인 $200{ }^{\circ} \mathrm{C}$ 를 선정하였다. 마지막으로
$\mathrm{PSA}$ 의 경우에는 장치 도입 흐름의 수분 함유량이 $0.7 \%$ 이하가 되는 조건을 고려하여 운전 조건을 설정하였다.

식 (2)에서와 같이 이론적으로는 글리세롤 1 몰을 이용하여 수소 7 몰을 생산할 수 있으나, Table 2 을 보면 초기에 글리세롤 0.25 몰을 투입하여 수소 1.315 몰을 생성하는 것을 볼 수 있다. 이는 수소 수율이 약 $75.1 \%$ 에 해당하는 것으로, 2.3절에서 설명했던 미국 $\mathrm{DOE}$ 와 독일 Linde의 경우와 동일한 PSA 조건으로 비교하였을 경우에는 효율이 가장 좋은 것으로 나타났다. 최종적으로 생산되는 수소는 $31.1 \mathrm{Nm}^{3} / \mathrm{h}$ 로 목표했던 $30.0 \mathrm{Nm}^{3} / \mathrm{h}$ 를 달성하였다. Fig. 7은 기본 공정의 PFD이다.

전체 공정 중에서 상대적으로 높은 에너지 소비를 보인 단계는 히터, 개질기, 컴프레서 순으로 총 $302,030 \mathrm{~kJ} / \mathrm{h}$ 의 에너지를 사용하게 된다. 이는 천연가스 저열가(Low Heating Value, LHV)인 $47.141 \mathrm{MJ} / \mathrm{kg}$ 을 적용할 경우 약 $6.4 \mathrm{~kg} / \mathrm{h}$ 이며, 산업통상자원부 고시(2014/01/01) LNG 수입가격인 $807.44 \mathrm{USD} / \mathrm{ton}$ 을 적용할 경우 약 $5.2 \mathrm{USD} / \mathrm{h}$ 에 해당한 다. 본래는 수소 $1 \mathrm{~kg}$ 당 드는 생산비용을 $\mathrm{USD} / \mathrm{kg} \mathrm{H}_{2}$ 의 단위로 표 현해야 하지만 본 연구에서는 개념설계를 진행하였기 때문에 장치비는 고려하지 않은 관계로 공정에서 시간당 소비되는 금액으로 표시하였다.

\section{4-2. 최적화를 통한 공정 개선}

기존 공정의 에너지 효율을 높이기 위하여 공정의 개선을 통한 에 너지 최적화를 실시하였다. 에너지 소비가 가장 큰 장치인 히터, 개 질기, 컴프레서의 에너지 소비량은 식 (9)와 같다.

$$
\mathrm{Q}_{\text {tot }}=\mathrm{Q}_{h t}+\mathrm{Q}_{r f}+\mathrm{Q}_{\text {comp }}
$$

Fig. 8 는 개선된 공정의 PFD이며, Table 3 는 개선된 공정의 Flow Chart 이다. 공정에서 가장 많은 에너지를 사용하는 곳은 수증기 개질 반

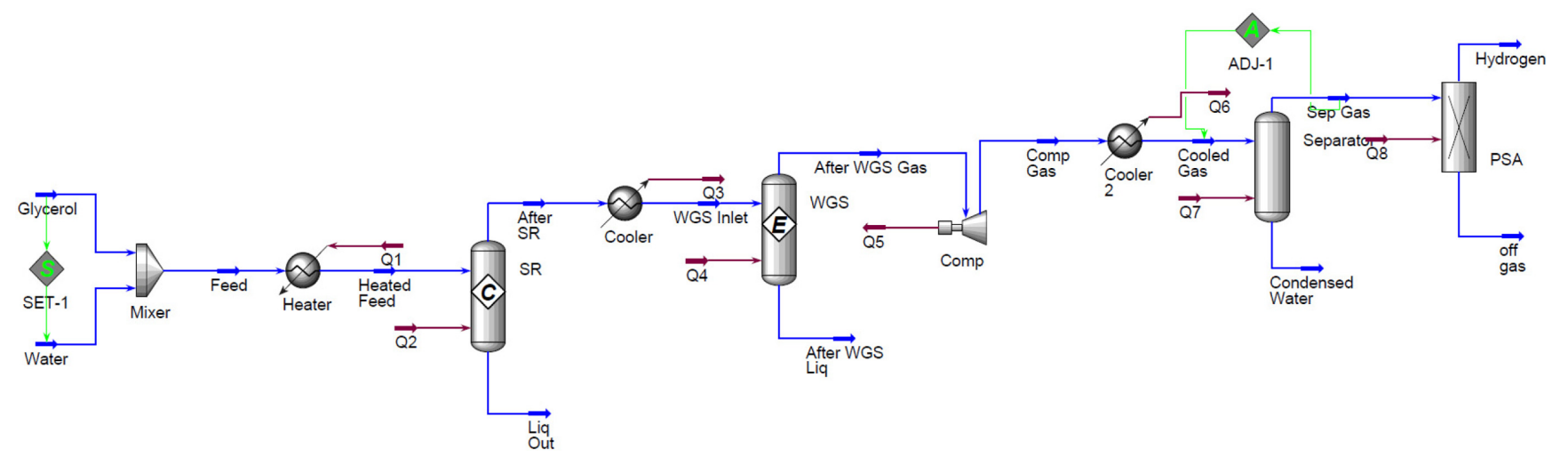

Fig. 7. Basic process flow diagram.

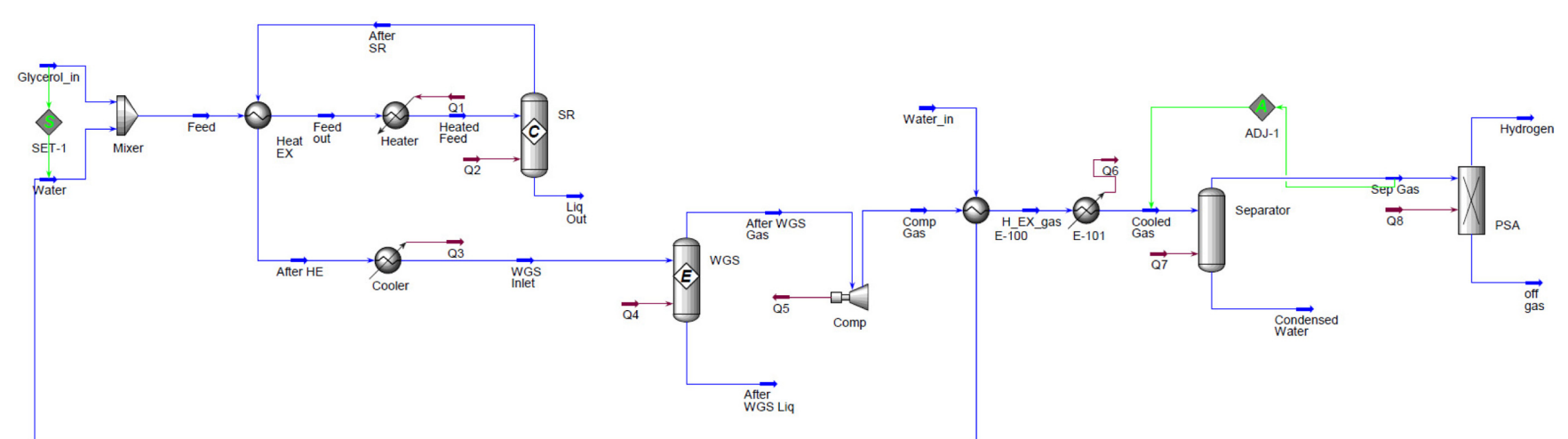

Fig. 8. Improved process flow diagram. 
Table 3. Flow sheet of improved process

\begin{tabular}{|c|c|c|c|c|c|}
\hline Name & Glycerol & Water & Feed & After SR & Heated Feed \\
\hline Vapour Fraction & 0.0000 & 0.0000 & 0.0000 & 1.0000 & 1.0000 \\
\hline Temperature (C) & 25.00 & 125.1 & 98.76 & 800.0 & 800.0 \\
\hline Pressure $(\mathrm{kPa})$ & 506.6 & 506.6 & 506.6 & 304.0 & 506.6 \\
\hline Molar Flow (kgmole/h) & 0.2500 & 2.250 & 2.500 & 3.941 & 2.500 \\
\hline Mass Flow (kg/h) & 23.02 & 40.53 & 63.56 & 63.00 & 63.56 \\
\hline Std Gas Flow (STD_m³ $/ \mathrm{h})$ & 5.911 & 53.20 & 59.11 & 93.18 & 59.11 \\
\hline Name & After WGS Gas & After WGS Liq & Cooled Gas & Condensed Water & Sep Gas \\
\hline Vapour Fraction & 1.0000 & 0.0000 & 0.6001 & 0.0000 & 1.0000 \\
\hline Temperature (C) & 200.0 & 200.0 & 32.79 & 32.79 & 32.79 \\
\hline Pressure $(\mathrm{kPa})$ & 202.6 & 202.6 & 709.3 & 709.3 & 709.3 \\
\hline Molar Flow (kgmole/h) & 3.941 & 0.0000 & 3.941 & 1.576 & 2.365 \\
\hline Mass Flow (kg/h) & 63.00 & 0.0000 & 63.00 & 28.43 & 34.56 \\
\hline Std Gas Flow (STD_m³ $/ \mathrm{h})$ & 93.18 & 0.0000 & 93.18 & 37.26 & 55.91 \\
\hline Vapour Fraction & 1.0000 & 0.9873 & 1.0000 & 0.0000 & 1.0000 \\
\hline Temperature (C) & 26.40 & 26.40 & 200.0 & 800.0 & 324.3 \\
\hline Pressure $(\mathrm{kPa})$ & 709.3 & 709.3 & 304.0 & 304.0 & 709.3 \\
\hline Molar Flow (kgmole/h) & 1.315 & 1.049 & 3.941 & $4.427 \mathrm{e}-002$ & 3.941 \\
\hline Mass Flow (kg/h) & 2.651 & 31.91 & 63.00 & 0.5623 & 63.00 \\
\hline Std Gas Flow (STD_m³ $/ \mathrm{h}$ ) & 31.10 & 22.48 & 93.18 & 1.047 & 93.18 \\
\hline Name & Feed out & After HE & Water_in & H_EX_gas & \\
\hline Vapour Fraction & 0.3512 & 1.0000 & 0.0000 & 1.0000 & \\
\hline Temperature (C) & 159.1 & 469.7 & 25.00 & 200.0 & \\
\hline Pressure $(\mathrm{kPa})$ & 506.6 & 304.0 & 506.6 & 709.3 & \\
\hline Molar Flow (kgmole/h) & 2.500 & 3.941 & 2.250 & 3.941 & \\
\hline Mass Flow (kg/h) & 63.56 & 63.00 & 40.53 & 63.00 & \\
\hline Std Gas Flow (STD_m³ $/ \mathrm{h})$ & 59.11 & 93.18 & 53.20 & 93.18 & \\
\hline Heat Flow $(\mathrm{kJ} / \mathrm{h})$ & $1.595 \mathrm{e}+005$ & $6.118 \mathrm{e}+004$ & $3.595 \mathrm{e}+004$ & $-2.885 e+004$ & $-1.685 e+004$ \\
\hline Name & Q6 & Q7 & Q8 & & \\
\hline Heat Flow $(\mathrm{kJ} / \mathrm{h})$ & $9.030 \mathrm{e}+004$ & 0.0000 & -982 & & \\
\hline
\end{tabular}

응기 도입 직전에 원료를 가열하는 히터, 수증기 개질 반응기 내부, 컴프레서 순이며 이 장치들에서 사용되는 에너지의 사용량을 줄이는 것을 통해 공정에서 사용되는 에너지를 절약할 수 있다. 또한 WGS 반응 후, PSA 도입 조건인 수분 $0.7 \%$ 이하 조건을 만족시키기 위하 여 냉각을 통해 수증기를 응축시켜 제거하게 되는데, 냉각 과정에서 버려지는 폐열을 재활용하면 에너지를 더욱 절약할 수 있다. 아래 식 (10)은 개선후의 공정에서 필요로 하는 열량을 계산하기 위한 식이다.

$$
\mathrm{Q}_{\text {improve }}=\mathrm{Q}_{h t}+\mathrm{Q}_{r f}+\mathrm{Q}_{\text {comp }}-\mathrm{Q}_{\text {exn } 1}-\mathrm{Q}_{\text {exn } 2}-\mathrm{Q}_{\text {off }}
$$

먼저 히터에 사용되는 에너지는 히터 도입 직전에 열교환기를 통 하여 수증기 개질반응을 거치고 나온 흐름과 열 교환을 하여 미리 가 열한다. 이를 위하여 공정에 열교환기를 추가한 결과, 히터에서 소비 되는 에너지가 $224,000 \mathrm{~kJ} / \mathrm{h}$ 였던 것이 $159,500 \mathrm{~kJ} / \mathrm{h}$ 로 줄어들면서 약 $28.8 \%$ 의 감소효과를 나타내었다. 또한 원료로 투입되는 물의 경 우에는 글리세롤과 혼합하기 전에 WGS 이후 흐름과의 열교환을 통 하여 초기 도입 압력인 5 기압일 때의 끓는점인 $151.8^{\circ} \mathrm{C}$ 보다 약간 낮은 온도인 $125^{\circ} \mathrm{C}$ 까지 예비 가열 후 글리세롤과 혼합한다. 이를 통해 약 $17,070 \mathrm{~kJ} / \mathrm{h}$ 의 에너지를 회수할 수 있으며, 이는 공정 개선 전에 냉각기 에서 버려지는 에너지인 $107,400 \mathrm{~kJ} / \mathrm{h}$ 의 $16 \%$ 에 해당한다.
$\mathrm{PFD}$ 에는 표시하지 않았지만 Fig. 4의 개선된 개념도에서 표현한 바와 같이 PSA 단계 이후 방출되는 잔여가스에 포함된 수소를 가열 기를 이용하여 연소시켜 히터와 수증기 개질 반응기에 필요한 열량 을 충당하는 방법도 고려할 수 있다. 잔여가스의 경우 대부분이 이 산화탄소로 이루어져 있어 환류를 하기에는 부적절하고, WGS 과정 이후 생산된 수소의 $20 \%$ (잔여가스 $1 / 3$ )가 존재하기 때문에 반응기나 히터의 열원으로 사용하여 에너지 비용을 낮출 수 있다. 연료의 효율을 고려하지 않는다고 가정할 경우 잔여가스의 LHV는 약 $59,250 \mathrm{~kJ} /$ $\mathrm{kmol}$ 로 몰 흐름인 $0.9508 \mathrm{kmol} / \mathrm{h}$ 를 고려하면 $56,335 \mathrm{~kJ} / \mathrm{h}$ 에 해당한 다. 이는 가장 큰 에너지 소비원인 히터, 개질기, 컴프레서에서 소비 되는 에너지 총량인 $237,530 \mathrm{~kJ} / \mathrm{h}$ 의 $23.7 \%$ 에 해당한다.

이와 같은 최적화를 통해 히터, 개질기, 컴프레서에서 소비되는 에 너지를 $181,195 \mathrm{~kJ} / \mathrm{h}$ 까지 낮출 수 있었으며 이는 최적화 직전의 필 요 열량인 $302,000 \mathrm{~kJ} / \mathrm{h}$ 의 $60 \%$ 에 해당한다. 4.2 절에서 $\mathrm{LNG}$ 비용을 토대로 계산했던 시간당 소비 연료비용을 동일하게 적용했을 경우, 약 $3.1 \mathrm{USD} / \mathrm{h}$ 로 기존 $5.2 \mathrm{USD} / \mathrm{h}$ 에 비해 $2.1 \mathrm{USD} / \mathrm{h}$ 만큼 절약이 가능하였다. 이는 공정에서 소비되는 에너지 비용 면에서 연간 $18,400 \mathrm{USD}$ 의 절약을 의미하며, 기존 공정 대비 $40 \%$ 의 비용 절 감에 해당한다. 최적화에 의한 개선 공정은 Table 4에 요약되어 있다. 
Table 4. Changes in energy consumption

\begin{tabular}{lcccc}
\hline \hline & Heater & Reformer & Compressor & Total energy \\
\hline Basic process $(\mathrm{kJ} / \mathrm{h})$ & 224,000 & 61,180 & 16,850 & 302,030 \\
Improved process $(\mathrm{kJ} / \mathrm{h})$ & 159,500 & 4,845 & 16,850 & 181,195 \\
Change amount $(\mathrm{kJ} / \mathrm{h})$ & $-64,500$ & $-56,335$ & 0 & $3.1 \mathrm{USD} / \mathrm{h}$ \\
\hline
\end{tabular}

Table 5. Comparison of economics with similar process

\begin{tabular}{ccc}
\hline \hline & $\begin{array}{c}\text { Hydrogen yield } \\
\text { (PSA recovery 86\%) }\end{array}$ & $\begin{array}{c}\text { Moles of hydrogen production } \\
\text { per 1mol glycerol }\end{array}$ \\
\hline Linde & $77.5 \%$ & $5.43 \mathrm{~mol}$ \\
DOE & $74.2 \%$ & $5.19 \mathrm{~mol}$ \\
Proposed process & $80.7 \%$ & $5.65 \mathrm{~mol}$ \\
\hline
\end{tabular}

\section{4-3. 유사 공정 대비 경제성 검토}

글리세롤 이용한 수소 생산공정에서 언급했던 Linde와 DOE에 대 해 비교한 결과를 Table 5 에 나타내었다. 공정 전체적인 경제성을 비 교하기에는 각 공정의 조건들이 다르기 때문에 정확한 비교는 할 수 없어서 생산된 수소의 수율을 이용하여 비교를 실시하였다.

생산된 수소의 수율은 개질기 및 WGS 반응기뿐만 아니라 PSA과 정에 의해서도 차이가 발생했고, 이중 PSA 단계는 세 경우 모두 가장 좋은 효율을 보인 Linde사의 $86 \%$ 회수율을 적용하여 계산했다. 이와 같은 방법에 의하여 비교한 결과, 본 연구의 결과가 $80.7 \%$ 로 가장 높은 수소 수율을 보였고, Linde는 $77.5 \%$, DOE는 $74.2 \%$ 로 가장 낮은 수소 수율을 나타내었다.

\section{5. 결 론}

이 연구에서는 공정 설계 및 시뮬레이션 프로그램을 이용하여 30 $\mathrm{Nm}^{3} / \mathrm{h}$ 규모의, 글리세롤로부터 수소를 생산할 수 있는 공정을 설계 하였다. 초기 개념설계를 기반으로 하여 열교환기의 추가 및 반응기 와 히터의 열 공급원으로 잔여가스 내에 남아있는 수소를 이용하는 등의 최적화 과정을 거쳐 기본 공정에 비해 에너지 비용이 $2.1 \mathrm{USD} / \mathrm{h}$ 만큼 향상된 수소 생산 공정을 제시하였다. 미국 셰일가스의 여파로 천연가스의 가격이 낮아져 당분간은 글리세롤을 이용한 수소 생산 공정이 경제성 측면에서는 천연가스에 비해 경쟁력이 떨어지지만, 장차 바이오디젤 시장의 성장과 더불어 글리세롤의 생산량도 많아지 고, 그로 인한 단가의 하락과 더불어 바이오디젤 산업의 지속가능성 제고 노력도 요구되기에, 특히 소규모 수소 스테이션을 위한 글리세 롤을 이용한 수소 생산은 경쟁력을 가지게 될 것이라고 예상된다.

\section{감 사}

이 연구는 2013년 한국산업기술평가관리원의 지원으로 수행된 연 구입니다(글리세롤 이용 수소 제조 및 글리세롤의 고부가 전환공정 개발, No 10033687).

\section{References}

1. BP, "BP Statistical Review of World Energy 2013"(2013).

2. Tan, H. W., Aziz, A. R. A. and Aroua, M. K., "Glycerol Production and Its Applications as a Raw Material: A Review,' Renew- able and Sustainable Energy Reviews, 27, 118-127(2013).

3. Kim, D. W., Park, K. A., Kim, M. J. and Park, D. W., "Catalytic Performance of Ionic Liquids in the Synthesis of Glycerol Carbonate from Glycerol and Urea,' Korean Chem. Eng. Res., 51, 347-351(2013).

4. Chen, Y., Wang, Y., Xu, H. and Xiong, G., "Efficient Production of Hydrogen from Natural Gas Steam Reforming in Palladium Membrane Reactor,' Applied Catalysis B: Environmental, 80, 283-294(2008).

5. Tamhankar, S., "Green Hydrogen by Pyroreforming of Glycerol," WHEC(2012).

6. Ahmed, S. and Papadias, D., "Hydrogen from Glycerol: A Feasibility Study,' DOE Hydrogen Program(2009).

7. Adhikari, S., Fernando, S., Gwaltney, S. R., To, S. D. F., Bricka, R. M., Steele, P. H. and Haryanto, A., "A Thermodynamic Analysis of Hydrogen Production by Steam Reforming of Glycerol," Int. J. Hydrogen Energy, 32, 2875-2880(2007).

8. Adhikari, S., Fernando, S. and Haryanto, A., "Kinetics and Reactor Modeling of Hydrogen Production from Glycerol via Steam Reforming Process over $\mathrm{Ni} / \mathrm{CeO}_{2}$ Catalysts,' Chem. Eng. Technol., 32(4), 541-547(2009).

9. Huang, Z.-Y., Xu, C.-H., Liu, C.-Q., Xiao, H.-W., Chen, J., Zhang, Y.-X. and Lei, Y.-C., "Glycerol Steam Reforming over $\mathrm{Ni} / \gamma-\mathrm{Al}_{2} \mathrm{O}_{3}$ Catalysts Modified by Metal Oxides,' Korean J. Chem. Eng., 30(3), 587-592(2013).

10. Sundari, R. and Vaidya, P. D., "Reaction Kinetics of Glycerol Steam Reforming Using a $\mathrm{Ru} / \mathrm{Al}_{2} \mathrm{O}_{3}$ Catalyst', Energy Fuels, 26, 41954204(2012).

11. Adhikari, S., Fernando, S. and Haryanto, A., "Hydrogen Production from Glycerol: An Update,' Energy Convers. Manage., 50, 2600-2604(2009).

12. Choi, Y. and Stenger, H. G., "Water Gas Shift Reaction Kinetics and Reactor Modeling for Fuel Cell Grade Hydrogen,' J. Power Sources, 124, 432-439(2003).

13. Smith, R. J. B., Loganathan, M. and Shantha, M. S., "A Review of the Water Gas Shift Reaction Kinetics,' Int. J. Chemical Reactor Eng., 8(1), 1-34(2010).

14. Yang, S. I., Park, J. Y., Jang, S. C., Choi, D. Y., Kim, S. H. and Choi, D. K., "Experiment and Simulation of 4-bed PSA for Hydrogen Separation from Multi-Component Mixture Gases,' Korean Chem. Eng. Res., 46(2), 414-422(2008).

15. Chou, C., Chen, F., Huang, Y. and Yang, H., "Carbon Dioxide Capture and Hydrogen Purification from Synthesis Gas by Pressure Swing Adsorption,' Chem. Eng. Trans., 32, 1855-1860(2013). 